\title{
The future of theology at a public university
}

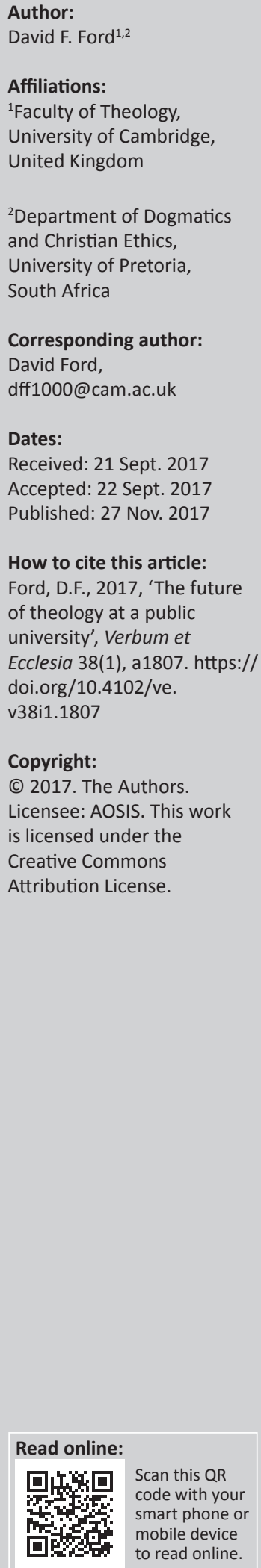

In exploring the future of theological reflection at a public university, the Irish Anglican theologian David Ford considers the study of theology in university settings that are multireligious and multi-secular. He discusses the responsibilities of such universities with regard to the religions, and how they can be healthily diverse places with a pluralism of multiple depths. He proposes an understanding of theological reflection as a wisdom-seeking inquiry open to all as the preferable approach in such universities. Against the background of appreciative remarks on contextual trends and developments within theological reflection worldwide and other profound engagements such as between Christian thought and philosophy, the human and natural sciences, but also with new voices such as women's, postcolonial and marginalised groups, Ford describes his viewpoint on the practice of Scriptural Reasoning. In his description, Ford indicates how such a practice at a public university can shape a better future in which the societal importance of religion in a healthily plural world is respected. It entails the taking on of specific responsibilities by the public universities, acknowledging their privileged spaces within our societies and fostering a healthy pluralism of multiple depths.

Intradisciplinary and/or interdisciplinary implications: In exploring the future of theological reflection at a public university, the article addresses the philosophical, theological and educational fields of reflection within an integrated perspective developed from a wisdomseeking practice, namely, Scriptural Reasoning to establish and justify the societal significance of such reflection for ensuring a healthy pluralism with multiple depths in a plural world.

\section{The future of theology at a public university}

This article marks the occasion of the centenary of the Faculty of Theology at the University of Pretoria. It seeks to do justice to the achievement of that faculty in developing the study of theology in a university setting, connects this with other academic approaches to the religions and sets the faculty's achievement in international perspective.

I begin with some relevant personal remarks.

I first met with the vice-chancellor and principal of the University of Pretoria, Professor Cheryl de la Rey, at another centenary celebration, that of the Association of Commonwealth Universities, in London. I was struck in particular by three things. One was the weight she carried in that company of international university leaders. Another was her overall vision for her university and how to go about realising it. The third was her enthusiasm for the development of both theology and other ways of studying the religions. When I later met with the dean of the faculty, Professor Johan Buitendag, and then studied the 2016 'Plan and Agreement' envisioning the future of the faculty, I realised that the leadership and vision in theology have been of a similar calibre. Then in Pretoria I met a wide range of other faculty members, both staff and students, and was struck by their commitment to being the sort of faculty that, as I will discuss below, has the type of shape and purpose that seems to me best suited to the 21st century.

It was particularly good to be at the University of Pretoria during a year in which the beginning of the Reformation was being remembered. Pretoria's Faculty of Theology was deeply shaped by the Reformed tradition, and my own debts to that tradition are many. I am an Irish Anglican born in the Republic of Ireland, but with family also in the more Presbyterian Northern Ireland. One of my grandmothers was from the Netherlands, from a strongly Reformed background in Groningen. I wrote my doctoral dissertation on the theology of Karl Barth. My favourite 20th century

Note: This article is a revised version of an address delivered at the Centenary Celebration of the Faculty of Theology, University of Pretoria, on July 29th 2017. 
philosopher is Paul Ricoeur. And someone to whom I owe a great deal is Professor Iain Torrance, a member of one of the most distinguished Presbyterian theological families of the past century, who has been both moderator of the Church of Scotland and president of Princeton Theological Seminary. That combines the Irish, Dutch, Swiss, French, Scottish and American Reformed traditions, and now the South African can be added. The Reformed commitment and contribution to intellectual excellence, not just in theology but across the board in all disciplines and areas of university life around the world, has been second to none. And my appreciation of that has been enhanced by learning how, at the University of Pretoria, Reformed theology is now involved in shaping a setting that is hospitable to other Christian traditions, to other religions and to the best secular understanding.

There is much for Pretoria's Faculty of Theology to celebrate in 2017. The faculty is the leading university centre for theology in Africa. Not only that, it is one of the top centres in the world, now officially recognised as such by the most reliable of the league tables. And, perhaps just as important, the word on the academic street confirms this. Not just the faculty's publications but also its collaborations, its international hospitality and the quality of its graduates are all having an impact. The faculty has come a long way in the past century; but now, as its open-ended centenary strapline, 'A Gateway To ...', suggests that the big question is about the future, which is the main focus of this article.

\section{Multi-religious and multi-secular universities}

Firstly, some basic thoughts about this.

Universities are a remarkable global network of institutions that have multiplied during the past century and become increasingly important. They now play a leading role in global civilisation, educating most of those in positions of power and influence, and they are essential to the knowledge economy, the learning society and the information age. They engage with most contemporary discourses, disciplines, technologies, industries, professions, institutions and spheres of life in our world. ${ }^{1}$

This world is not simply secular or simply religious: it is multi-religious and, to coin a term, multi-secular, with many complex hybrids. But it is sad that many universities are still stuck in the 20th century. They are caught in a conception of the world that seems to take for granted an ideologically secular framework. For them, modernity means moving in a linear way from a religious past to a secular future. They have not faced the fact that over $80 \%$ of the world's population are directly involved in some religion, or that, because of higher birth rates among the religious, this is likely to have increased by 2050 . Nor have they grasped that there are multiple modernities, some more religious, others less so.

1.For my further thoughts on the history and contemporary shaping of universities see Ford (2007a:Chapter 9) 'An interdisciplinary wisdom: knowledge, formation and collegiality in the negotiable university' (Ford 2007a:304-349).
Nor do they take seriously that there are millions and millions of religious people who are highly educated in the sciences, the humanities, medicine, engineering, management, communications and so on. Nor have they recognised that one of the great needs of our world is for thoughtful, intelligent, well-educated faith and belief, and for thoughtful, intelligent, well-educated understanding of faith and belief whatever one's own faith or belief.

One of the tragedies resulting from that common 20th century secularist mindset is that in the past century many universities have been founded that do not take the religions seriously; and in many other universities academic engagement with the important questions raised by religions, about religions and between religions has been marginal. ${ }^{2}$ This has not only meant that such universities are effectively blind, or at best one-eyed, in relation to a huge dimension of human meaning and life, but it has also negatively affected public discourse about the religions and policy towards them, and it has contributed to the intellectual impoverishment of the religions themselves.

\section{Universities, the religions and wisdom: Responsibilities, healthily plural spaces and a pluralism of multiple depths}

What might universities (and here I have public universities mainly in mind) now do about this to shape a better future in the 21 st century?

Firstly, they can recognise that they have a threefold responsibility: to engage academically with religion and belief; to help improve public discourse and policy in relation to the religions; and to serve the religious traditions by critical and constructive contributions to their understanding and practice, just as they do to other spheres of life such as business, health, politics and sustaining the ecosystem. ${ }^{3}$ There is no reason whatsoever why those spheres, but not religion, should be treated with academic seriousness.

Secondly, public universities are privileged spaces in our multi-religious and multi-secular societies, where staff and students of many faiths and beliefs come together. Universities therefore have the opportunity to sponsor engagements across differences that can help our diverse, plural societies flourish. This can be done through teaching; through research; through a culture of conversation,

2.This was probably only conceivable in a situation where so many Western-educated intellectuals seemed to take for granted a worldview in which there was a linear progression for religious societies of the past to secular societies in modernity. There has been a shift, among some at least, to recognizing that the world is predominantly religious in various forms, and that there are many types of modernity - some more secular, some more religious, with mostly an array of hybrids.

3.Observing students over several decades in the universities where I have taught, my conclusion is that these correspond roughly to the three main motivations students state for studying the subject: fascination by one or more of the range of disciplines state for studying the subject: fascination by one or more of the range of disciplines that engage with the refions in the contemporary word; and personal interest in throug participation in a religious community but also as seekers. Often students affirm two or all three. The main difference I have noticed in recent years is that the public importance of the religions weighs more than previously. 
discussion and debate; through the whole ethos of an institution; and through its practical involvements in society - regional, national and international. We have no choice about whether our public universities and societies are plural; the great question is whether and how they can be healthily plural.

Thirdly, to be healthily plural is to appreciate and nurture the depth, richness and long-term fullness of life present in each major tradition at its best. It is no good having a university or public sphere of shallow tolerance, where no one can speak and act from the heart of their understanding and commitment. We need a pluralism of multiple depths deep Christianity, deep Judaism, deep traditional religion, deep Islam, deep Hinduism, deep and humane secular belief and understanding, and so on. And those multiple depths need to be in conversation and, if possible, in collaboration with each other for the sake of the common good. That should be an essential ingredient in any recipe for a flourishing university, society or civilisation. It is hard to think of any place more suited to this in-depth engagement than universities.

And running through each of those three points about responsibilities, healthily plural spaces and a pluralism of multiple depths is the need for wisdom. This is partly about offering an education that, as well as understanding, knowledge and know-how, seeks to share wisdom (which includes the ethical handling of the power given by that knowledge and know-how); but it is also about how the university shapes itself in vital matters. Those matters include its own good governance; the interrelation of teaching and research; the interrelation of disciplines; the formation of students; its forms of collegiality and community; and its responsibilities towards regional, national and international flourishing (Ford 2007:Chapter 9).

All of that involves extremely difficult judgements and decision-making, and the balancing of responsibilities towards diverse stakeholders - in other words, it cries out for wisdom. That complex task needs to be resourced as richly as possible, able to draw on many traditions of wisdom-seeking, both religious and secular, and it is crucial that these traditions be academically mediated through relevant disciplinary and cross-disciplinary thinking, argument, teaching and research.

\section{Wisdom-seeking theology in the public university}

And what about theology?

Relatively few of the world's universities have what I consider by far the best way to engage academically with the religions in a university. That is to cultivate theology as a wisdom-seeking inquiry open to all.

There are four key elements in this sort of theology:
- Firstly, it pursues questions of meaning, truth, beauty and practice raised by, about and between ${ }^{4}$ the religions, and it can be both critical and constructive.

- Secondly, theology has responsibilities towards the whole range of academic disciplines that have to do with the religions, so it best flourishes in interaction with other fields of inquiry and with what are sometimes called the areas of religious studies or study of religion. It is good that the Faculty of Theology here will soon change its name to the Faculty of Theology and Religion. ${ }^{5}$

- Thirdly, it also has responsibilities towards the living religious traditions to which billions of people belong, to help those traditions in their scriptural and historical understanding, in their wisdom-seeking engagement with other religious and non-religious traditions and with modernity, and in their critical and constructive thinking. This does not mean doing all the training of their clergy or other religious professionals, though it can contribute greatly to this. But to have members who pursue theology in a university setting is a huge resource for any tradition, and ideally that setting is one where they can engage with those who belong to many religious traditions or none, and with the full range of academic disciplines.

- And, fourthly, theology has responsibilities towards the common good of society - local, national and global. ${ }^{6}$

Its overall responsibility in a public university, in a world where there is so much foolish faith, dangerous faith, ignorant faith, and utterly inadequate public understanding of faith, might be seen as working, with others, for wiser, more intelligent and more responsible faith and belief, and wiser, more intelligent and more responsible understanding of faith and belief, all for the sake of the flourishing of a healthily plural world. But, in order to do this, its pluralism needs to be one with multiple depths, and to have collegiality among those who go as deeply as possible into the wisdom of

Roughly speaking, theology might be seen as dealing with the questions raised by the religions, and the study of religion, or religious studies, as dealing with the questions raised about the religions. It is the questions raised between the religions that best act as a catalyst for seeing the importance of having university settings where the two cohabit. In order to engage fully with these interreligious issues, it greatly helps to have both theological and study of religion perspectives on each of the religions being dealt with

5.In Ford (2011:Chapter 9) 'New Theology and Religious Studies' concluded with tasks and maxims recommended to those with institutional responsibility for the field: Develop rationales for the field, not just in the fairly general terms I have used, but also in Jewish, Christian, Muslim, Hindu, secular and other terms. Then bring the also in Jewish, Christian, Muslim, Hindu, secular and other terms. Then bring the rationales into dialogue with each other and build departments and institutions
that can be justified and nourished by more than one tradition.
Whatever the nature of the settlement in one's own department, make the case Whatever the nature of the settlement in one's own department, make the case and being supportive of the overall diverse ecology of new theology and religious
and studies.

Develop rich descriptions of the field, both historical and contemporary, using the field's academic disciplines to do so.

Hold together the three trans-generational responsibilities towards universities, religious communities and societies, and build forms of collegiality around each responsibility.

Seek the good of the whole field of theology and religious studies, and put intellectual and political energy into debates about its future in order to help it become 'mutual ground' (rather than 'neutral ground') for those of many religions and none.

Seek funding for the field, and especially endowments, as the best material way to ensure long term flourishing.

Have a global vision for the field, commensurate with the global presence of the religions, and embody this not only in the curriculum but also, whenever possible, in the teaching and student body, in institutional alliances and in responsibilities undertaken (Ford 2011:166-167).

6.For more on these points, see Ford (2007b). 
particular traditions, communicate as deeply as possible with those who are deep into other traditions, and collaborate with these and others for the sake of the common good.

\section{A personal testimony: Universities, the most fruitful theological century and Scriptural Reasoning}

I want to make two further sets of remarks about the sort of university theology that I have been describing.

The first set is personal.

I have had the immense privilege of studying, researching, examining and teaching in universities in several countries where that sort of wisdom-seeking theology happens. It happens now in my original alma mater, Trinity College Dublin, where I studied classics. It happens in the universities where I studied theology - Cambridge, Yale and Tübingen. It happens in the universities where I have taught full-time Birmingham and Cambridge. It happens in other universities where I have lectured or examined, including Oxford, Durham, Edinburgh, Aberdeen, King's College London, the Free University of Amsterdam, Duke, Harvard, Chicago and Murdoch in Australia. I even see some Chinese universities tentatively opening up towards it. ${ }^{7}$ I am immensely grateful that, in all these places, I have been able to be a Christian theologian, joining with others in theology and in religious studies in responsibilities towards the academy, the church and society.

As a Christian theologian, I think the project that has been most educational for me during my career has been working on three editions of a textbook on Christian theology since 1918, The Modern Theologians (Ford \& Muers 2005). That stretched my theological horizons to appreciate what I came to regard as the most fruitful century in the whole history of Christian theology. I began to learn more of what has been going on in Asian, African (Professor Tinyiko Maluleke, now in Pretoria, wrote on African Theology for the third edition), Latin American and other regions' theologies; in Pentecostal, Evangelical, Orthodox and other denominational theologies; and in the profound engagements between Christian thought and philosophy, the human and natural sciences, other faiths, ethics and politics, the arts, film, spirituality and more. But, above all, there have been the new voices: women's, ethnic, post-colonial, charismatic and many marginalised groups. So, during the lifetime of Pretoria's Faculty of Theology, the field of academic Christian theology has flourished as never before, and all the signs are that this century could be even better.

I think the most surprising thing that I have experienced in my career has been the development of Scriptural Reasoning over the past 20 years. It began with some of us Christians sitting on the edge of a fringe group of Jewish text scholars, philosophers and theologians, called Textual Reasoning, at

7.For example, see below on Minzu University. the American Academy of Religion in the early 1990s. They had extraordinarily lively, intense, argumentative sessions around texts from the Jewish Bible (Tanakh), Talmud and modern Jewish thinkers, and there was also much laughter. Then some of them and some of us formed Scriptural Reasoning, and soon after Muslims joined in, with passages from Tanakh, Bible and the Qur'an on the table. ${ }^{8}$

Now the practice has spread around the world and beyond the Abrahamic faiths. The Institute for Comparative Scripture and Interreligious Dialogue does it at Minzu University in Beijing, where they study not only Abrahamic texts but also Confucian, Daoist and Buddhist texts; Professor Marianne Moyaert teaches a course of 60-80 students every year on Scriptural Reasoning at the Free University of Amsterdam; there are doctoral and masters courses on it at the University of Virginia, where the initiative on religion, politics and conflict also draws on Scriptural Reasoning in its research on how to understand and respond to religion-related violence; it happens in many nonacademic settings - hospitals in Israel/Palestine; church, synagogue and mosque congregations in many countries; leadership courses; peace-building projects; prisons; and schools; in July 2017, I took part in a packed Scriptural Reasoning seminar with Christian and Muslim students at the University of Tübingen, led by Professors Lejla Demiri and Christoph Schwöbel'; next year there will be a new centre for Hindu, Christian and Muslim Scriptural Reasoning at an Indian university, Dev Sanskriti Vishwavidyalaya in Haridwar; and in the United Kingdom, Rose Castle in Cumbria has become the hub for Scriptural Reasoning beyond the academy and the home of the website http:/ / www.scripturalreasoning.org.

For me, Scriptural Reasoning has been the embodiment of healthily plural collegiality: at its best, its practice of intensive conversation around rich texts enables participants go deeper into their own tradition, deeper into those of others and deeper into the common good of the world we share, creating a pluralism of multiple depths - and often also being a catalyst for surprising and enduring friendships across deep differences.

\section{The University of Pretoria, Faculty of Theology and life in its fullness}

The second set of remarks concerns the Faculty of Theology (soon to become the Faculty of Theology and Religion) at the University of Pretoria. It does this sort of theology too. As I spoke with your vice-chancellor and later with Professor Buitendag, and then read the faculty's strategic plan for the future, I was surprised and impressed by how all the key elements are present: depth in particular traditions; being critical and constructive in teaching and research; bringing together a range of disciplines and achieving internationally recognised academic excellence; breadth and diversity of

8.For an account of Scriptural Reasoning by Jewish, Muslim and Christian participants, see Ford and Pecknold (2006) and Ford and Clemson (2013)

9.1 have been impressed by what is happening in some German universities, as in Tübingen, where there is a deliberate and well-funded effort to develop Islamic Tubingen, where there is a deliberate and well-funded effort to develop Islamic
theology to the same high standard of Christian theology, and also to enable engagement between the two, as through Scriptural Reasoning. 
religious and secular engagement; being responsible towards the wider society in this country, the rest of Africa and internationally; and more.

On the occasion of the celebration of the faculty's centenary, I want simply to say to both the faculty and the university: treasure what you have; realise how important a niche it is in the world's academic ecosystem; and continue to cultivate it, because it is vital for the sake of what you have taken as your watchword: 'life in its fullness'.

\section{A Centenary Gift: 'I have crossed famous rivers'}

The remainder of this article is likewise addressed directly to the Faculty of Theology, with the hope that it might be relevant much more widely.

Firstly, I want to give you a little centenary gift, in the form of part of a poem about Nelson Mandela.

Here is some background to the poem. Some years ago I went through a slow immersion in Mandela's life. I had gone with my then 12-year-old son, Daniel, to Dublin to my mother's home but had forgotten to bring The Lord of the Rings, the bedtime book I was in the course of reading to him. I took down instead, from a shelf of my mother's books, Mandela's autobiography, Long Walk to Freedom and began reading it to him. From the opening account of Mandela's rural boyhood, Daniel was captivated. So, in the weeks following I had the moving experience of reading it slowly with him, punctuated by many questions and conversations, as we both savoured and puzzled over the story of one of the past century's most remarkable people. I recommended the book to my friend, the poet Micheal O'Siadhail, and he later wrote the poem I will now quote, called 'I've Crossed Famous Rivers'. I begin half way through it, as the poet draws on Mandela's long distance running to describe him:

pathfinder, painstaker, a cross country pacemaker moving dangerously out ahead.

Even as a boy to win but never to humiliate. Discipline inscribed in years and genes of grit, a stubborn smile that seems to begin in an eye

of a student once expelled for making a stand, a tearaway eluding a planned tribal match, a gardener of Robben Island sharing among

prisoners and warders his overspill of fruits, Antigone crying at Creon's unlistening will. For 28 years never to stand still

Even on the same spot wearing out a shoe to keep on and on running no matter what. Talk, plot, debate, argument, growth.

Decades of gestation. A small village boy he'd whiten his hair with ash in imitation of his beloved father. Now parent to a nation.

Nkosi sikelel iAfrika. God bless Africa.

Laps of honour in a stadium of success.

Forgiveness. To win but never to humiliate.
Under a frost of grey a wise smile creases.

Yes, to father a country, but to have lost

my children's laughter? I've crossed famous rivers. (O'Siadhail 2013:586, Quoted with permission)

\section{Three encouragements: The Long Haul; Daring; Humiliation and Community}

There are two encouragements that might be drawn from that poem by your faculty, as you enter your second century in uncertain times.

Firstly, you need to take the long view, grateful for those 10 'decades of gestation' you have had, and approaching the future as a long distance runner like Mandela, hoping that the university, the religious communities, the government - and some generous third stream funders are also in for that long haul across generations - and being willing to do the necessary Talk, plot, debate, [and] argument to help that happen.

And secondly, you need the confidence, the faith and hope that are open to moving dangerously out ahead. There are things in your strategic plan that will only be realised if you are willing to be as daring as Mandela, as well as having something of his endurance, patience and discipline, decade after decade.

And there is a third encouragement. Mandela was passionately concerned for the humiliated, and also determined not to perpetuate the cycle of humiliation and the violence associated with it. As O'Siadhail's poem says, Even as a boy to win but never to humiliate ... Forgiveness. To win but never to humiliate. He was also utterly dedicated to building community. Now parent to a nation ... Yes, to father a country. So this encouragement is about the connection between humiliation and community, and I owe it to a conversation with Jean Vanier.

Jean Vanier is the founder of the International Federation of L'Arche Communities, in which people with and without serious learning disabilities live together in family-like households. He has also written a profound commentary on the Gospel of John, and for the past 13 years I have been trying to write a commentary on John too. When he was awarded the Templeton Prize a couple of years ago, my wife and I were guests at a celebration of it, and I asked him how he now understood Chapter 19 of John's Gospel - the story of the passion and crucifixion of Jesus.

He gripped my arm as he spoke, and this is what he said:

At the beginning of that chapter, Jesus is humiliated - he is flogged, a crown of thorns is pressed into his head, he is mocked, and slapped in the face.

The people with learning disabilities in our communities have been humiliated too. They have been seen as of no worth, having 
no dignity. They have been marginal to what other people really value and centre their lives on: knowledge, education and work; sex, marriage, family life and friendship; health, sport and beauty; and power, wealth and fame.

Then Jesus is nailed to the cross, and what does he do from there? When he sees his mother and the disciple he loved at the foot of the cross, he says to his mother, 'Woman, here is your son', and to the disciple, 'Here is your mother.'10 Then John says that the disciple took her into his home. So, out of the depths of humiliation Jesus creates a community. 'At the heart, the root, of this community', said Vanier, 'is the humiliated one'.

I see the L'Arche communities, and the writings of Jean Vanier and of others associated with him, including his remarkable sister, Thérèse Vanier, and five academics, Henri Nouwen, Stanley Hauerwas, Frances Young, Hans Reinders and John Swinton, as prophetic for our century, and perhaps especially for our universities, where learning ability is so central. Learning ability is a genuine good, a great gift to be valued. But there are also the further questions: How does our learning ability serve the common good? Does it help to enable a community of compassion, generosity and love? Does it value as infinitely precious the dignity of each person, including the marginal and the humiliated? There is no international university league table for measuring all that, but in the end it is what matters most of all.

10.'When Jesus saw his mother and the disciple whom he loved standing beside her he said to his mother, "Woman, here is your son." Then he said to the disciple, "Here is your mother." And from that hour the disciple took her into his own home' (Jn 19:26-27). There is a chapter on L'Arche in Ford (2007a).

\section{Conclusion}

So, in conclusion, I pray that this faculty in the coming century may be a blessing to this university, to this wonderful country and continent, and to our gloriously diverse, plural, rainbow world; and that you may be willing, like Nelson Mandela, to move 'dangerously out ahead', especially as you attend theologically both to the depths of wisdom in each tradition you study, and to the urgent cries of fellow human beings - including those with learning disabilities - and of the rest of creation.

\section{Acknowledgements Competing interests}

The author declares that he has no financial or personal relationships that may have inappropriately influenced him in writing this article.

\section{References}

Ford, D.F., 2007a, Christian wisdom. Desiring God and learning in love, Cambridge University Press, Cambridge.

Ford, D.F., 2007b, Shaping theology. Engagements in a religious and secular world, Blackwell, Oxford.

Ford, D.F., 2011, The future of Christian theology, Wiley-Blackwell, Oxford.

Ford, D.F. \& Clemson, F. (eds.), 2013, Interreligious reading after Vatican II: Scriptural reading, comparative theology and receptive ecumenism, Wiley-Blackwell, Oxford.

Ford, D.F. \& Muers, R. (eds.), 2005, The modern theologians. An introduction to Christian theology since 1918, 3rd edn., Blackwell, Oxford.

Ford, D.F. \& Pecknold, C.C. (eds.), 2006, The promise of scriptural reasoning, Blackwell, Oxford.

O'Siadhail, M., 2013, Collected poems, Bloodaxe Books, Tarset, p. 586. 